\title{
Seroprevalence of human Trypanosoma cruzi infection in diferent geografic zones of Chiapas, Mexico
}

\author{
Soroprevalência da infecção humana pelo Trypanosoma đuzi \\ em diferentes regioes de Chiapas, México
}

\begin{abstract}
Miguel Angel Mazariego-Arana1, Victor M. Monteón², Martha Alicia Ballinas-Verdugo², Nidia Hernández-Becerril ${ }^{2}$, Ricardo Alejandre-Aguilar ${ }^{3}$ and Pedro A. Reyes ${ }^{2}$
\end{abstract}

\begin{abstract}
A serologic survey was carried out in four different geographic zones of Chiapas, Mexico. A total of 1,333 samples were collected from residents of thirteen communities located on the Coast, Central Mountain, Lacandon Forest and a zone called Mesochiapas. One hundred and fifty one seropositive individuals (11.3\%) were identified. Human Trypanosoma cruzi infection was influenced by geography. In the Lacandon Forest and Central Mountains there was a higher seroprevalence 32.1 and $13.8 \%$ respectively, than on the coast (1.2\%). In Mesochiapas there were no seropositive individuals among the 137 persons tested. An active transmission is probably continuing because seropositive cases (13.8\%) were detected in children under 10 years of age. The vector recognized on the Coast was Triatoma dimidiata while in the Lacandon Forest it was Rhodnius prolixus.
\end{abstract}

Key-words: Chagas' disease. Trypanosoma cruzi. Seroprevalence. Seroepidemiologic survey.

Resumo Foi feito um estudo sorológico em quatro zonas geográficas do estado de Chiapas México. Foram colhidas 1333 amostras dos habitantes das 13 comunidades situadas na costa, na região central montanhosa, na floresta lacandona e na região chamada mesochiapas. Cento cinqüenta e uma pessoas (11,3\%) foram identificadas como soropositivas. A infecção pelo Trypanosoma cruzi teve a influência da geografia local. Na floresta lacandona nas montanhas centrais, foi encontrada uma prevalência de 32,1 e 13,8\% respectivamente, mais que na costa 1,2\%. Na zona de mesochiapas não foi encontrada nenhuma pessoa com sorologia positiva entre 137 estudadas. Como encontramos sorologia positiva em crianças menores de 10 anos, pensamos que exista uma transmissão ativa contínua. Na costa foi reconhecido o vetor Triatoma dimidiata e na floresta Lacandona o Rhodnius prolixus.

Palavras-chaves: Doenca de Chagas. Trypanosoma cruzi. Soroprevalência. Estudo Soropidemiológico

Chagas' disease has been identified in Mexico since $1940^{5}$. Epidemiological surveys carried out in different geographical regions of the Country have revealed a heterogeneous distribution of infection. Endemic zones have been identified mainly in the coastal and southern regions with high seropositivity in rural villages, as well as cases of chronic human disease $\mathrm{7}^{721314}$. Chiapas, a southern state, showed both characteristics: tropical and subtropical climate and high rural conditions.

In 1983, Goldsmith et al ${ }^{1}$ reported $3.6 \%$ of seropositivity in human beings in Chiapas. The more recent National Seroepidemiological survey ${ }^{15}$ identified
Chiapas as the highest seropositive state in Mexico, up to $5 \%$ in open population, while in voluntary blood donors Trypanosoma cruzi infection was $1.8 \%{ }^{2}$. A serologic survey carried out in Chilón, a rural municipality in Chiapas, showed $29 \%$ seropositivity in 1993 (VM, personal unpublished data).

The objective of this work was to update seroepidemiological data. A survey on 1,333 volunteers collected samples from residents of thirteen communities in four geographic zones within Chiapas revealed a relatively high seropositivity and suggested active transmission.

1. Facultad de Ciencias Quimicas-Campus IV UNACH. Tapachula Chiapas, México. 2. Laboratorio de Imunoparasitología. Instituto Nacional de Cardiología I. Chávez. 3. Departamento de Parasitologia. Escuela Nacional de Ciencias Biológicas. Instituto Politécnico Nacional

Financial support: Conacyt grant number 30944-M

Address to Dr. Pedro A. Reyes. Instituto Nacional Cardiología I. Chávez. Juan Badiano 1, Tlapan México DF 14080.

Tel: (52) 55732911 ; Fax (52) 55730994

e-mail: preyes @yahoo.com or victormonteon@hotmail.com

Recebido para publicação em 10/11/2000. 


\section{MATERIAL AND METHODS}

Population. Thirteen communities were visited by one of the authors (MAM). The study population was composed of open population in rural regions within Chiapas State, whose seropositivity for $T$. cruzi had been previously reported in $1983^{1}$. The people were informed in detail about the protocol in the presence of local authority. In those places where Spanish is poorly understood a translator was used. Usually the translator was also the moral authority in the community. Only those people who consented to take part in this study were involved in the protocol. A venous blood sample and personal information such as name, age and gender were obtained. In many of the communities, the people refused to give any additional information because Chiapas is a region undergoing political conflict.

The protocol was approved by the Ethics Committee of the University of Chiapas.

Serological studies. Indirect Hemagglutination test (IHA) was used as the first screening test and performed according to the manufacturer's instructions (Wiener Lab). In brief, sera dilutions from 1:2 up to 1:256 were carried out. No end-point titer was done. Positive and negative controls were run in parallel. Samples were incubated for 90 minutes and agglutination read. Cut-off dilution was 1:8. All sera were submitted to the Central Laboratory where Indirect Immunofluorescence and ELISA tests were performed.

ELISA test. The ELISA test was used as screening assay in the Central Laboratory and performed as previously reported with minor modifications ${ }^{10}$ : One $\mathrm{mg}$ of the T. cruzi (Ninoa Mexican strain) extract per well in alkaline-buffered solution was plated and blocked with PBS-Tween 20 solution and $1 \%$ bovine serum albumin concentration (PBS-TA). Human experimental 1:400. Anti-human IgG -peroxidase conjugated was used at 1:10000. Incubation time was 5 minutes for all steps mentioned above. After the addition of $\mathrm{O}$ phenylendiamine, the reaction was read at 490nm. Cut-off of 0.34 ODU was obtained by the media +5 SD and positive and negative control sera were diluted at

of 30 healthy individuals. Our ELISA test shows a correlation of Kappa index above 0.8 , sensitivity up to $92 \%$ and specificity of $95 \%$, as previously reported 6 .

Indirect Immunofluorescence (IIF). Samples that yield positive results in any of both tests mentioned above were submitted to IIF. The assay was performed as reported ${ }^{10}$. In brief, a drop of epimastigote (Ninoa Mexican Strain) suspension was air dried on a slide. Human experimental and control sera were then diluted at 1:32 (cut-off dilution) in PBS and incubated in a humidified chamber for 30 minutes. The slides were then washed and incubated with the conjugate antihuman IgG fluorescein for 30 minutes. After incubation, the slides were observed by epifluorescent microscopy. If fluorescence of the parasites was observed, the sample was scored as positive.

ELISA and IIF in the Central Laboratory have been previously standardized and validated. Sensitivity was $100 \%$ and specificity $95 \% 68$.

Combined positive results of at least two positive made a serum to be declared as positive.

Environment description. Coast of Chiapas State: is a 30-kilometer wide plain between the Pacific Ocean coastline and mountains. Small alluvia's are interrupted by rivers, swamps, and ponds.

Mesochiapas: is a 30 to 60 kilometer wide central depression parallel to the mountain central zone with an altitude between 1,000 to 1,500 meters.

Central Mountains: the central highlands contain two sub-zones, the central massif, composed of plateaus from 1,000 to 2,300 meters covered by coniferous forest, and the Northern Mountains an area of 20 kilometers $x 70$ kilometers, reaches 2,000 meters above sea level.

Lacandon Forest: extends east-ward to Guatemala, dropping rapidly from 1,500 meters to 100 meters at the Usumacinta River. It is a tropical evergreen forest ${ }^{10}$.

Statistical analysis. Descriptive methods were used.

\section{RESULTS}

From the 1,333 voluntary participants studied, 694 $(52 \%)$ were males and $639(48 \%)$ female. The mean age was $22.39(+/-) 16.6$. There was a similar rate of seropositivity in regard to gender, $70(46.3 \%)$ in males and $81(53.6 \%)$ in females (data not shown). Localization of the areas studied are shown in Figure 1.

The population studied was distributed as follows: From Mesochiapas 137 (10.3\%), Coast 631 (47.3\%), Lacandon forest 355 (26.6\%) and Central Mountains $210(15.8 \%)$. Seroprevalence rate differed between the geographical areas. The Lacandon Forest had a higher level $114 / 355(32 \%)$ followed by the Central Mountains $29 / 210(13.8 \%)$ and in the Coast only $8 / 631$ (1.2\%), no seropositive cases were detected in the 137 individuals collected in Mesochiapas. The presence of serum antibodies reactive with $T$. cruzi in two or three assays was $11.3 \%(151 / 1,333)$ Table 1.

Reactive serum antibodies against $T$. cruzi were present for all age groups, but in some villages, such 


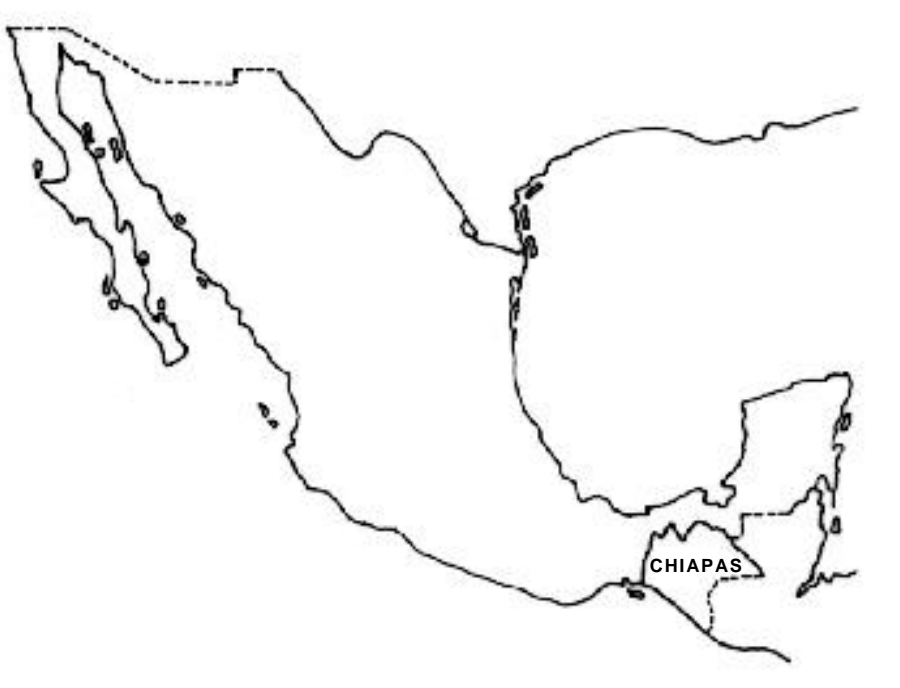

ESTADO DE CHIAPAS

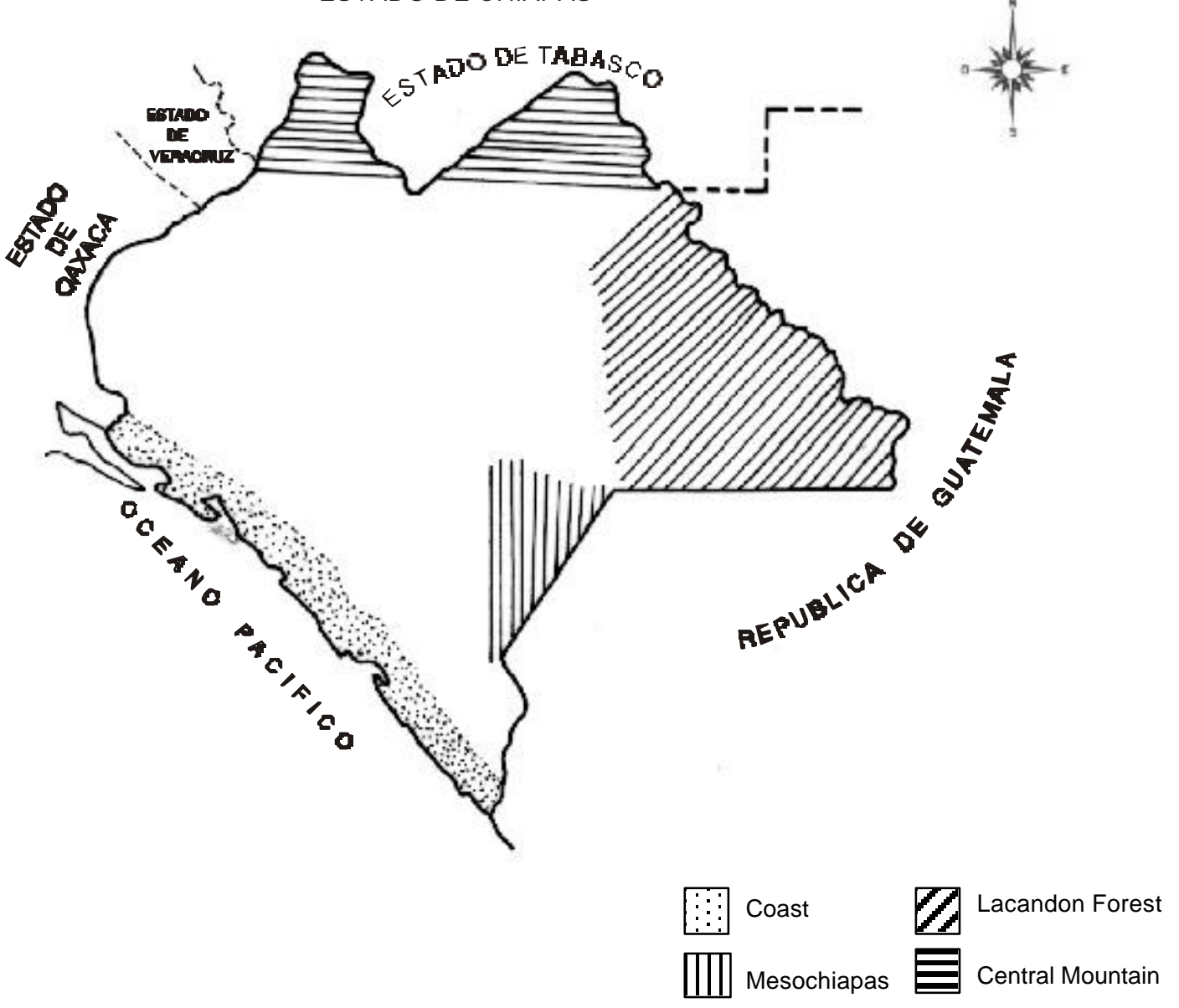

Figure 1 - Localization of the areas Chiapas State. 


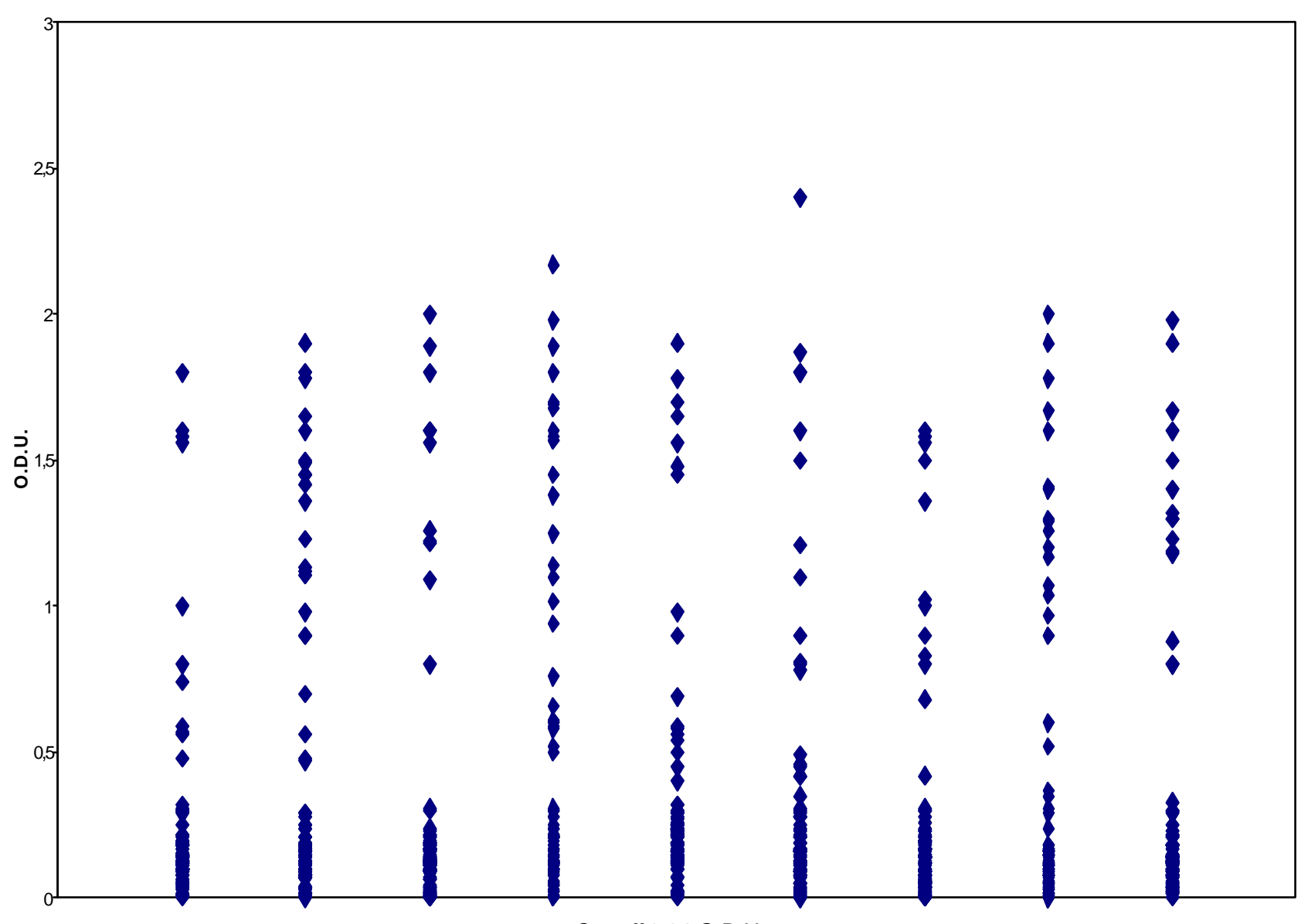

Cut-off 0.34 O.D.U.

Figure 2 - ELISA Test in 1,333 individuals.

Table 1 - Seroprevalence of Trypanosoma cruzi infection in four geographic zones of State of Chiapas, Mexico.

\begin{tabular}{llll}
\hline Zone & Communities & Positive/tested & $\%$ \\
\hline Mesochiapas & Frontera Comalapa & $0 / 137$ & 0 \\
& Ejido La Gloria & $0 / 66$ & 0 \\
Cojido La Línea & $0 / 46$ & 0 \\
& Ejido E. Zapata & $0 / 119$ & 0 \\
& Ejido El Topón & $1 / 72$ & 1,4 \\
& Acapetahua & $7 / 139$ & 5,0 \\
& Ejido Rio Florido & $0 / 14$ & 0 \\
& Ejido Morelos & $0 / 63$ & 0 \\
\hline Subtotal & Puerto Madero & $0 / 112$ & 0 \\
\hline Central Mountain & & $8 / 631$ & 1,27 \\
& Ejido Leon Brindis & $29 / 210$ & 13,8 \\
Lacandon Forest & Ejido Nuevo Jerusalem & $64 / 128$ & 50,0 \\
& Ejido Arimatea & $33 / 90$ & 36,6 \\
\hline Subtotal & Ejido Nueva Galilea & $17 / 137$ & 12,4 \\
\hline Total & & $114 / 355$ & 32,1 \\
\hline
\end{tabular}


as Nueva Galilea and Nueva Jerusalem, located within Lacandon forest seropositive cases among children under 10 years old were detected in 12/92 (13\%). Seropositivity of $23 \%$ up to $26 \%$ was observed in those groups aged above 21 years, while in the younger individuals it was around $10 \%$ (Table 2).

All the samples were submitted to either IHA or ELISA screening tests. The IHA was carried out in the field and ELISA at the Central Laboratory. There were discrepancies between these tests as shown in Table 3 and Figure 2.

By IHA 184 were positive and 1149 negative, while in ELISA 151 were positive and 1182 negative. One hundred and forty four were positive and 1142 were negative by both techniques. These data gave a sensitivity of $95 \%$ and specificity of $96 \%$ with positive and negative predictive values of $78 \%$ and $99 \%$, respectively. By IHA $25 \%$ of the positive population tested positive at 1:8 dilution. IIF was in accordance with ELISA.

Table 2 - Seroprevalence by age and geographic zone.

\begin{tabular}{|c|c|c|c|c|c|c|c|}
\hline \multirow{2}{*}{$\begin{array}{l}\text { Age group } \\
\text { (years) }\end{array}$} & \multicolumn{2}{|c|}{ Coast } & \multirow{2}{*}{$\begin{array}{c}\text { Central Mountain } \\
\text { Leon Brindis } \\
\%\end{array}$} & \multicolumn{3}{|c|}{ Lacandon forest } & \multirow{2}{*}{$\begin{array}{l}\text { Total } \\
(\%)\end{array}$} \\
\hline & $\begin{array}{l}\text { Topon } \\
\% \\
\end{array}$ & $\begin{array}{c}\text { Acapetahua } \\
\% \\
\end{array}$ & & $\begin{array}{c}\text { N. Jerusalem } \\
\% \\
\end{array}$ & $\begin{array}{c}\text { Arimatea } \\
\% \\
\end{array}$ & $\begin{array}{c}\text { N. Galilea } \\
\%\end{array}$ & \\
\hline & $0 / 9$ & $1 / 2$ & $0 / 22$ & $5 / 19$ & $0 / 6$ & $7 / 73$ & $13 / 131$ \\
\hline \multirow[t]{2}{*}{$1-10$} & 0 & 50 & 0 & 26.3 & 0 & 9.6 & 9.9 \\
\hline & $0 / 15$ & $2 / 37$ & $4 / 94$ & $21 / 44$ & $3 / 18$ & $4 / 22$ & $34 / 230$ \\
\hline \multirow[t]{2}{*}{$11-20$} & 0 & 5.4 & 4.2 & 47.7 & 16.6 & 18.2 & 14.8 \\
\hline & $0 / 13$ & $0 / 31$ & $6 / 20$ & $15 / 25$ & $13 / 27$ & $2 / 20$ & $36 / 136$ \\
\hline \multirow[t]{2}{*}{$21-30$} & 0 & 0 & 30 & 60 & 48.1 & 10 & 26.5 \\
\hline & $1 / 15$ & $2 / 30$ & $7 / 29$ & $13 / 22$ & $2 / 10$ & $3 / 14$ & $28 / 120$ \\
\hline \multirow[t]{2}{*}{$31-40$} & 6.6 & 6.6 & 24.1 & 59 & 20 & 21.4 & 23.3 \\
\hline & $0 / 12$ & $1 / 16$ & $5 / 24$ & $6 / 11$ & $7 / 13$ & $1 / 4$ & $20 / 80$ \\
\hline \multirow[t]{2}{*}{$41-50$} & 0 & 6.3 & 20,8 & 54.5 & 53.8 & 25 & 25 \\
\hline & $0 / 8$ & $1 / 23$ & $7 / 21$ & $4 / 7$ & $9 / 16$ & $0 / 4$ & $21 / 79$ \\
\hline \multirow[t]{2}{*}{$>51$} & 0 & 4.3 & 33.3 & 57.1 & 56.3 & 0 & 26.6 \\
\hline & $1 / 72$ & $7 / 139$ & $29 / 210$ & $64 / 128$ & $33 / 90$ & $17 / 137$ & $151 / 776$ \\
\hline Total & 1.38 & 5.0 & 13.8 & 50 & 36.6 & 12.4 & 19.5 \\
\hline
\end{tabular}

Table 3 -Titer dilution of 184 Seropositives by IHA test CHAGASTEST (WIENER-LAB).

\begin{tabular}{lrlllrrr}
\hline Community & $1: 8$ & $1: 16$ & $1: 32$ & $1: 64$ & $1: 128$ & $1: 256$ & Total \\
\hline Acapetahua & 5 & 3 & 1 & 1 & & & 10 \\
El Topón & 3 & & 1 & & & & 4 \\
Léon Brindis & 8 & 5 & 4 & 2 & 5 & 11 & 35 \\
Nueva Jerusalem & 10 & 4 & 5 & 7 & 12 & 33 & 71 \\
Arimatea & 12 & 5 & 8 & 6 & 5 & 3 & 39 \\
Nuevo Galilea & 8 & 5 & 1 & 7 & 2 & 2 & 25 \\
\hline Total & 46 & 22 & 20 & 23 & 24 & 49 & 184 \\
\hline
\end{tabular}

\section{DISCUSSION}

Human Trypanosoma cruzi infection and Chagas' disease have been identified in Mexico for over five decades. Geographic distribution of the infection has shown that higher rates are present in the Coastal and Southern part of the Country ${ }^{7121314}$, below the Tropic of Cancer, with a tropical/subtropical climate and usually under 2,000m above sea level.

The present work, studied Chiapas State, in the Southern part of Mexico, and found a clear difference in the infection rate within the four geographic zones. The highest seroprevalence rate was observed in the Lacandon Forest $32 \%$, followed by the Central Mountains $13.8 \%$, while on the Coast it was only $1.26 \%$ and no seropositive cases were identified in Mesochiapas. Findings of seroreactivity in individuals under 10 years old among inhabitants of Lacandon Forest, may suggest that an active transmission to human beings is taking place. Unfortunately, no epidemiological data was obtained regarding index of infestation, knowledge of the vector or percentage of parasited bugs. However, in those places where volunteers allowed a search for the bugs, the vector was located basically in the roof of their houses. In the Lacandon Forest a very precarious housing condition exists, up to $73 \%$ of their houses are made 
of palms leaves or other natural materials. The bug's eggs are carried on this material and the vector becomes domiciliated. This housing condition is less frequent on the coast.

Our data are similar in some extent to that reported by Goldsmith in 1983'. The main difference occurs in the Lacandon Forest. Higher seroprevalence was obtained in our survey $32 \%$ compared to $8.6 \%$ by Goldsmith. Also on the coast, we found $1.3 \%$, while Goldsmith reported no cases. These differences could be explained by the fact that different serological tests were performed. This study used an immunoenzymatic test that is more sensitive than haemaglutination, moreover they used a high positive cut-off titer of 1:128 that could have affected their sensitivity.

The irregular rate of seropositive distribution within the state of Chiapas could be because of housing conditions and geographic differences in addition to the kind of vector. In the Central Mountains and on the Coast Triatoma dimidiata has been reported previously ${ }^{11}$ and now has also been identified by us. In Lacandon Forest Rhodnius prolixus was implicated. It is known that triatomine feeding-behavior may play an important role in transmission of the infection ${ }^{4}$. Rhodnius prolixus is more aggressive than Triatoma dimidiata and it is more likely that this condition may have an influence in the rate of human infection. A higher rate of seroprevalence was observed in those regions with very poor housing conditions.

Although, discrepancies were detected between IHA and ELISA sensitivity and specificity was acceptable. The low positive predictive value observed could be due to the expertise in reading haemaglutination or another plausible explanation could be the antigen itself. In ELISA the antigen used is from Mexican isolate while IHA uses antigen from Argentina. It has been published that an autochthonous antigen improves serodiagnosis ${ }^{9}$. In Mexico there are few studies regarding the evaluation of diagnostics for Chagas' disease, and one of these was carried out between our Institution (Instituto Nacional de Cardiología) and the National Institute of Epidemiologic Reference (INDRE), showing a good correlation between them (Kappa index above 0.8) ${ }^{6}$. But it is necessary to expand this kind of study in order to evaluate the reagents and procedure in all those laboratories performing serodiagnosis for Chagas' disease. In conclusion, our data supports the hypothesis that seroprevalence within Chiapas State, Mexico is influenced by geographic, environmental and housing conditions and species of triatomine vector. It is important to further develop and obtain complete epidemiological information focusing in vector biology, reservoirs and diseased individuals in order to promote a control program for Chagas' disease.

\section{ACKNOWLEDGMENTS}

To Dr Fause Attie Cury who critically read the manuscript and helped us with a Portuguese written abstract.

\section{REFERENCES}

1. Golsmith RS, Ortega M, Zarate RJ, Zarate LG, Beltrán F. Seroepidemiologic surveys for Chagas'disease in Chiapas, México. Archivos Investigación Médica Mexico 14:43-50, 1983.

2. Guzmán-Bracho C, Garcia Garcia L, Floriani-Verdugo J, Guerrero MS, Torres CM, Ramírez MC, Velasco-Castrejón O. Riesgo de transmisión de Trypanosoma cruzi por transfusión sangre en México, Panamerican Journal Public Health 4:94-99, 1998.

3. Instituto Nacional de Estatistica, Geografía e informática. Palenque Estado de Chiapas. Cuaderno Estadistica Municipal, México, 1994.

4.- Lent H, Wygodzisky. Revision of the Triatominae (Hemiptera: Rediviidae) and their significance as vector of Chagas' disease. Bulletin American Museum National History 163:123-176, 1979.

5. Mazzotti L. Dos casos de enfermedad de Chagas en el Estado de Oaxaca. Gaceta Médica (México) 70:417-420, 1940.

6. Monteón VM, Guzmán-Bracho C, Floriani-Verdugo J, RamosEchavarria A, Velasco-Castrejón O, Reyes PA. Diagnóstico serológico de la enfermedad de Chagas: Autosuficiencia y concordancia interlaboratorios. Salud Pública (Mexico) 37:232235, 1995.

7. Monteón VM, Negrete-Garcia C, Reyes PA. Chronic Chagasic cardiopathy parasitemic state (Preliminary Report). Archives Medical Research 27:335-337, 1996.
8. Monteón VM, Sosa T, Reyes PA. Serological tests for american trypanosomiasis. A comparative study. Revista Latinoamericana de Microbiología 31: 35-38, 1989.

9. Pérez-Fuentes R, Sánchez-Guillen M, González-Alvarez C, Monteón V, Reyes PA, Rosales-Encina JL. Humoral nitric levels and antibody immune response of symptomatic and indeterminate Chagas' disease patients to commercial and autochthonous Trypanosoma cruzi antigen. American Journal Tropical Medicine 58:715-720, 1998.

10. Ramos-Echavarria A, Monteón VM, Reyes PA. Detección de anticuerpos contra Trypanosoma cruzien donadores de sangre. Salud Pública México 35:56-6, 1993.

11. Rojas J, Malo E, Espinoza-Medinilla A, Ondarza R. Selvatic focus of Chagas; disease in Oaxaca, México. Annals of Tropical Medicine and Parasitology 43:66-78, 1989.

12. Salazar PM, de Haro I, Uribarren T. Chagas' disease in Mexico. Parasitology Today 4:348-351, 1988.

13. Tay J, Salazar PM, Buccio MI. La enfermedad de Chagas en la República Mexicana. Revista Salud Pública México 22:409-450, 1980.

14. Velasco-Castrejón O, Guzmán-Bracho C. Importancia de la enfermedad de Chagas en México. Revista Latinoamericana de Microbiología 28:275-283, 1986.

15. Velasco-Castrejón O, Valdespino JL, Tapia-Conyer R, Salvatierra E, Guzmán-Bracho C, Magos C, Llausas A, Gitierrez G, Sepúlveda J. Seroepidemiología de la enfermedad de Chagas en México. Salud Pública México 34:186-196, 1992. 